\title{
VAZDUŠNA BOMBARDOVANJA SARAJEVA U DRUGOM SVJETSKOM RATU
}

\author{
Sead Vrana \\ Federalna uprava civilne zaštite \\ sead.vrana@fucz.gov.ba
}

\begin{abstract}
Apstrakt: Vazdušna bombardovanja Sarajeva tokom Drugog svjetskog rata pogodila su sve dijelove tadašnjeg gradskog područja. Većina žrtava bili su civili, a bombe su padale i na objekte bez vojne važnosti. Prve napade 1941. godine izvršilo je vazduhoplovstvo nacističke Njemačke, a od kraja 1943. godine bombardovanja su vršila saveznička vazduhoplovstva. Nad Sarajevom su dejstvovale i taktičke i strategijske snage bombama mase od 50 do $1800 \mathrm{~kg}$. Poređenjem podataka iz dostupnih arhiva vazduhoplovnih jedinica koje su vršile bombardovanja, zatim vojnih i civilnih vlasti u Sarajevu, te ranijih istraživanja vazdušnog rata, ovaj članak prikazuje koliki ratni napor je uložen u bombardovanja, na koje ciljeve je bio usmjeren, koja gradska područja je pogodio, kojom svrhom i kakvim rezultatom. Također, stavlja bombardovanja u historijski kontekst, kako bi rasvijetlio razloge koji su doveli do razornih posljedica po grad i stanovnike.
\end{abstract}

Ključne riječi: Drugi svjetski rat, Sarajevo, vazduhoplovstvo, vazdušna bombardovanja, Luftwaffe, USAAF, RAF

Abstract: Aerial bombardment during World War Two hit every part of the Sarajevo city area. Most of the victims were civilians as bombs fell on the buildings and areas which had no military significance. First attacks were executed by the Nazi Germany Luftwaffe, while from the end of 1943, the bombing was carried out by the Allied air forces. Both tactical and strategic forces operated over Sarajevo dropping bombs from 50 to 1800 kilograms. Through comparison of the data collected from the available archives of the 
aviation units which did the bombings and military and civilian authorities from Sarajevo, including previous researches of the air war, this article compiles the war effort put in the bombings, aimed targets, city areas which were stricken, the goals and the outcomes. It also puts the bombings into a historical context, to shed light on the reasons which led to the devastating consequences for the city and its citizens.

Keywords: World War Two, Sarajevo, air force, aerial bombardment, Luftwaffe, USAAF, RAF

Tokom Drugog svjetskog rata Sarajevo je pretrpilo značajna razaranja izazvanavazdušnim bombardovanjima, kakonjemačkim tako isavezničkim. Iako se ta bombardovanja učestalošću i žrtvama ne mogu ni blizu mjeriti sa bombardovanjima drugih evropskih gradova, nužno je naglasiti da su bombe padale na cijelu teritoriju grada od današnjih naselja Ilidža i Stup do Bistrika, Vratnika i Bembaše. Pogođeni su i objekti bez vojne važnosti, a najveće žrtve su izazvane među civilima. Od 2006. do 2019. godine na gradskom području Sarajeva je pronađeno deset neeksplodiranih bombi zaostalih iz Drugog svjetskog rata, ${ }^{1}$ koje su predstavljale opasnost od nekontrolisane eksplozije po ljude i imovinu u svojoj okolini. Stoga je istraživanje sile primijenjene $u$ bombardovanjima, $u$ smislu broja borbenih letova, vrste i količine bačenih bombi, te područja koja su pogođena, nužno za razumijevanje rizika i sprječavanje nekontrolisane eksplozije zaostale bombe. S druge strane, bez smještanja bombardovanja u historijski kontekst, nemoguće je razumjeti razloge zbog kojih su izvršena i izazvala žrtve.

Namjera autora ovog članka je da izvede što detaljniji prikaz ratnog napora uloženog u bombardovanja, ciljeva protiv kojih je bio usmjeren i posljedica koje je izazvao. S tim ciljem je istražena dostupna arhivska građa jedinica, koje su vršile bombardovanja iz sastava Kraljevskog ratnog vazduhoplovstva Velike Britanije (RAF) iz Nacionalne arhive Ujedinjenog

\footnotetext{
${ }^{1}$ Vidi: Newsroom. Informativna emisija- Televizija N1. 11. septembar 2019. dostupno: http://ba.n1info. com/Video/N1-Newsroom/a461012/Newsroom-11.9.2020.html (pristupljeno: 6. 5. 2020)
} 
kraljevstva i Američkog armijskog ratnog vazduhoplovstva (USAAF) iz arhive Agencije za istorijska istraživanja zračnih snaga preuzeta izravno ili putem memorijalnih sajtova jedinica. Dejstva njemačkih zračnih snaga (Luftwaffe) zbog nedostupnosti izvornih dokumenata proučena su posredno u radovima u kojima su obrađena. Arhivskim dokumentima vojnih vlasti u Sarajevu, Ministarstva oružanih snaga NDH (MINORS) pristupljeno je u Zborniku dokumenata i događaja Narodno-oslobodilačkog rata Vojnoistorijskog instituta iz Beograda, dok je dokumentima civilnih vlasti, Kotarskog nadzorništva narodne zaštite, pristupljeno u Historijskom arhivu grada Sarajeva. Pri upotrebi građe podaci suprotstavljenih snaga su davani uporedno za pojedinačna bombardovanja, jer je to najpogodniji način za prikazivanje potpune slike događaja. Kako bi bombardovanje Sarajeva bilo smješteno $\mathrm{u}$ historijski kontekst, korištena su dosadašnja istraživanja politika, doktrina i strategija vazdušnog rata koja se dotiču i Sarajeva, ali i vojnih operacija u okviru kojih su bombardovanja vršena. Sama dejstva su prikazana bez obzira da li se radi o napadu strategijske ili taktičke avijacije, ali je naglašeno koja je vrsta dejstva izvođena pri opisu pojedinačnih napada.

\section{Njemački vazdušni napadi na Sarajevo}

Dan nakon istupanja Kraljevine Jugoslavije iz Trojnog pakta, 27. marta 1941. godine, Hitler je donio Direktivu 25 - naređenje glavnoj komandi za invaziju i uništenje Jugoslavije. Ovom direktivom je između ostalog predviđeno, da čim uslovi dozvole, vazdušnim napadima budu uništeni zemaljski objekti jugoslovenskog vazduhoplovstva i glavni grad Beograd stalnim dnevnim i noćnim napadima. Za izvršenje ovih napada određene su 4. vazdušna flota (Luftflote), te VIII i X vazdušni korpus (Fliegerkorps) sa ukupno 6 bombarderskih grupa (Kampfgruppe), 11 grupa obrušavajućih bombardera (Stukagruppe), 11 grupa lovaca (Jagdgruppe) i 5 eskadrila lovaca (Jagdgeschwagder), 5 grupa teških lovaca (Zerstorergruppe), 2 izviđačke eskadrile, 1 hidroeskadrila i 13 eskadrila za vezu ukupne snage 1158 aviona, ${ }^{2}$

\footnotetext{
${ }^{2}$ Michael R. Barefield, Overwhelming Force, Indecisive Victory: The German Invasion of Yugoslavia,
} 
a operacija je nazvana “Odmazda” (Unternehmen Strafgericht).

Luftwaffe je 6. aprila 1941. godine izvršila prvo vazdušno bombardovanje područja Sarajeva u Drugom svjetskom ratu. U 07:30 sati 22 bombardera $\mathrm{X}$ Vazdušnog korpusa uz pratnju 15 lovaca na aerodrom Jugoslovenskog kraljevskog ratnog vazduhoplovstva Rajlovac bacili su 88 bombi od $250 \mathrm{~kg}$ i 220 bombi od $50 \mathrm{~kg}$, 3 ukupno 33 tone. Iako je u Hitlerovoj Direktivi 25 naglašeno uništenje Beograda, što je u praksi rezultiralo teškim razaranjem ovog grada, 12. i 13. aprila su također bombardovani rezidencijalni dijelovi Sarajeva, pri čemu su bombe pale uglavnom na civilne ciljeve. Nepoznata je količina i vrsta bombi koje su u dvodnevnim napadima bačene na sam grad, ali je i ove napade izvršio X vazdušni korpus, koji je u svom sastavu u vrijeme Aprilskog rata imao 4 bombarderske grupe, 1 grupu teških lovaca i jednu lovačku eskadrilu sa ukupno 168 aviona. ${ }^{4}$

Prvi objekti pogođeni bombama bili su zgrade Pošte i Suda, te željeznička stanica, hotel Zagreb, Cirkus-platz (područje oko današnjeg hotela Holiday), naselja Bistrik, Medrese i Bjelave, Hrid i Vratnik, gdje je pogođena osnovna škola. U ulicama Šenoinoj, 6. novembra, Masarikovoj, Skenderiji, Jakubovića bašči i Pionirskoj, bombama je srušeno nekoliko zgrada i kuća. Naročito je veliki broj žrtava bio u Velikom parku, gdje je bombom pogođeno sklonište i na Bembaši, gdje su se građani pokušali skloniti od bombardovanja. ${ }^{5}$ Smatra se da je u njemačkim bombardovanjima poginulo oko 90 stanovnika Sarajeva. ${ }^{6}$ Detaljni izvještaji o šteti i žrtvama iz tog perioda nisu sačuvani, a u sačuvanim dokumetima Kotarskog

1941, Fort Leavenworth: School of Advanced Military Studies United States Army Command and General Staff College, 1993, 48.

${ }^{3}$ Christopher Shores, Brian Cull, Air War for Yugoslavia, Greece and Crete, 1940-41, London: Grub Street, 1987, 205.

${ }^{4}$ M. R. Barefield, Overwhelming Force, Indecisive Victory, 48.

${ }^{5}$ Sulejman Šefkić, "Stradanja stanovništva od prvih bombardovanja”, u: Sarajevo u revoluciji, knjiga 2, Sarajevo: Istorijski arhiv Sarajevo, 1976, 80.

${ }^{6}$ Haris Zaimović, "Moderna historija Sarajeva pisana kroz 6. april (1): Sarajevo je do popodnevnih sati 6. aprila 1945. bilo potpuno slobodno", STAV, Sarajevo. 5. 4. 2018. https://stav.ba/modernahistorija-sarajeva-pisana-kroz-6-april-1-sarajevo-je-do-popodnevnih-sati-6-aprila-1945-bilopotpuno-slobodno (pristupljeno: 6. 5. 2020) 
nadzorništva narodne zaštite ili Gradskog poglavarstva, najraniji izvještaj o bombardovanju Sarajeva u Drugom svjetskom ratu odnosi se na saveznički napad od 25. novembra 1943. godine.

\section{Savezničke vazduhoplovne snage nad Balkanom}

Prva saveznička vazduhoplovna dejstva nad Jugoslavijom vršile su jedinice koje su nakon pobjede saveznika na sjevernoafričkom ratištu raspoređene u Italiji. USAAF je u Italiji stacionirao 12. vazdušne snage, koje su krajem 1943. godine u svom sastavu imale 6 grupa teških bombardera, 7 grupa srednjih i lakih bombardera, 11 lovačkih grupa, 3 transportne i 2 izviđačke grupe, te su vršile i strategijske i taktičke zadatke. ${ }^{7}$

RAF je u Italiji rasporedio jedinice iz nekoliko komandi koje su u svom sastavu imale formacije britanskog, australijskog (RAAF), kanadskog (RCAF), južnoafričkog (SAAF) i novozelandskog (RNZAF) vazduhoplovstva. Ove snage su se sastojale od 205. bombarderske grupe sa pet bombarderskih wingova, ${ }^{8}$ odnosno 10 skvadrona (eskadrila) od kojih je svaki formacijski imao 12 operativnih srednjih ili teških bombardera. Glavni zadaci 205. grupe su bila strategijska bombardovanja. ${ }^{9}$ Taktička dejstva Kraljevskih zračnih snaga na Mediteranskom vojištu izvršavala su 2 bombarderska i 7 lovačkih i lovačko-bombarderskih wingova sa ukupno 7 eskadrila lakih bombardera i 30 eskadrila lovaca i lovaca-bombardera iz sastava Pustinjskih vazdušnih snaga (DAF) i XII taktičke vazduhoplovne komande. ${ }^{10}$

Prvog novembra 1943. godine izvršile su prvu misiju 15. vazdušne snage USAAF-a, u čiji je sastav ušao 5. bombarderski wing sa 6 grupa

\footnotetext{
${ }^{7}$ Snaga grupe teških bombardera u USAAF-u iznosila je 48 aviona, a srednjih bombardera i lovaca 64 aviona.

${ }^{8}$ U USAAF-u wing formacijski odgovara diviziji, grupa puku, dok je u RAF-u obratno.

${ }^{9}$ Richard G. Davis, Bombing the European Axis Powers-A Historical Digest of the Combined Bomber Offensive 1939-1945, Maxwell Airforce Base, Alabama: Air University Press, 2006, 13.

${ }^{10}$ Dennis Richards, Hilary St. George Saunders, Royal Air Force 1939-1945, Volume II, The Fight Avails, London: HMSO, 1953, 391.
} 
teških bombardera iz 12. vazdušnih snaga. Do 10. maja 1944. godine ova komanda će biti popunjena sa 6 wingova sa 21 bombarderskom grupom snage 1512 teških bombardera. ${ }^{11}$ Osnovni zadatak ovih snaga bili su napadi na strateške industrijske i komunikacijske mete na teritoriji Trećeg Reicha, koje su bile van dometa bombardera iz Engleske, te strateški napadi na komunikacijske i političke mete u jugoistočnoj Evropi i na Balkanu. ${ }^{12}$

Prvi napad 15. vazdušnih snaga na teritoriji Jugoslavije je bio na Split 7. januara, a na teritoriji Bosne i Hercegovine na Mostar 8. januara 1944. godine. Prvi napad 205. grupe na Bosnu i Hercegovinu izvršen je 10. juna 1944. godine na rafineriju u Bosanskom Brodu. ${ }^{13}$

U junu 1944. godine formirana je posebna komanda Kraljevskog ratnog vazduhoplovstva, koja je nazvana Balkansko ratno vazduhoplovstvo (BAF) za taktička dejstva i koordinaciju dostavljanja pomoći vazdušnim putem nad Balkanom. Do oktobra 1944. godine u sastav ove komande ušlo je 19 lovačkih, lovačko-bombarderskih i jurišnih eskadrila, jedna eskadrila srednjih i tri lakih bombardera raspoređenih u 5 wingova, te dvije transportne eskadrile. ${ }^{14}$ Komanda BAF-a nalazila se u Bariju, a operativna dejstva su vršena sa aerodroma Canne i Bifferno, potom sa aerodroma na otoku Visu, a posljednjih mjeseci Drugog svjetskog rata sa aerodroma Prkos kraj Zadra. Prvu borbenu misiju BAF je izveo 1. jula 1944. godine u okolini Livna. ${ }^{15}$

\section{Saveznički bombarderski napadi na Sarajevo 1943-1945. godine}

Sporadične savezničke vazduhoplovne akcije nad Jugoslavijom počinju u septembru 1943. godine. Već u oktobru izvršene su prve bombarderske

${ }^{11}$ R. G. Davis, Bombing the European Axis Powers, 344.

${ }^{12}$ Kevin A. Mahoney, Fifteenth Air Force against the Axis: Combat Missions over Europe during World War II, Lanham, Toronto, Plymouth UK: The Scarecrow Press, inc, 2013, 4.

${ }^{13}$ G. R. Davis, Bombing the European Axis Powers, CD-ROM Table 1944-1.

${ }^{14}$ Jeff Jefford, “The Balkan Air Force”, u: Royal Air Force Historical Society Journal, no. 46, London: Royal Airforce Historical Society, 2009, 69.

${ }^{15}$ Isto, 74. 
misije na Gospić (8. oktobra), Kotor (10. oktobra), Skoplje (18. oktobra) i Niš (20. oktobra). ${ }^{16}$

Prvi saveznički bombarderski napad na Sarajevo izvršen je 25. novembra 1943. godine i s vojne strane je bio neuspješan. Bombarderi tipa B-25 Mitchell iz 321. i 340. bombarderske grupe 12. vazdušnih snaga USAAF-a zbog lošeg vremena i oblaka nad Sarajevom nisu vidjeli mete,$^{17}$ te su bacili samo 4 bombe, ${ }^{18}$ ukupno 0,9 tona. Bombe su pale između ulica Terazije i Urijan-dedina, gdje su se nalazila polja, te nisu napravile veću štetu osim nekoliko oštećenja izazvanih razbacanim kamenjem na području oko gradske elektrane (današnja ulica Valtera Perića). ${ }^{19}$

Naredno bombardovanje Sarajeva izvršeno je 29. novembra 1943. godine. Trideset dva srednja bombardera B-25 Mitchell poletjela su u izvršenje 162. misije 321. bombarderske grupe 12. vazdušnih snaga, bombardovanje željezničkih instalacija i kasarni u Sarajevu. U operativnom izvještaju ove misije stoji da su 27 od 32 bombardera bacila 162 bombe od 500 lbs $^{20}$ ukupne mase 36,7 tona, da su mete bile zaklonjene maglom i dimom, te da neke posade vjeruju da je na zemlji bila upotrijebljena dimna zavjesa. To je razlog zbog kojeg pogoci nisu osmotreni, te se vjeruje da su bombe razbacane na širem prostoru, iako su neke pale preko željezničke pruge. Također je uočena velika eksplozija blizu tvornice eksploziva. ${ }^{21}$

${ }^{16}$ J. C. Fitzgerald, '57thbombwing.com', $12^{\text {th }}$ Air Force, 57 Bombardment Wing, $321^{\text {st }}$ Bombardment Group, History: October 125. 1943, dostupno: http://57thbombwing.com/321stHistory/321_ BG_1943-10.pdf, 11.09.2013. (pristupljeno: 28. 4. 2020)

${ }^{17}$ Isto, November 130.

${ }^{18}$ Historijski arhiv Sarajevo (dalje: HAS), Kotarsko nadzorništvo narodne zaštite KNNZ-12, Kutija 1, Izvještaj povodom zračnog bombardiranja 25 XI 1943, Broj: 121/taj od 27. XI 1943.

${ }^{19}$ Isto.

${ }^{20}$ Lbs oznaka za imperijalnu jedicu mase libra koja odgovara 0,454 kilograma. Nominalna masa od 500 lbs odgovara masi od 227 kilograma. U RAF-u i USAAF-u najbliža zaokružena masa bombe je bila dio oznake tipa bombe, te je uzimana kao računska osnova bombarderskog tereta. Stvarna masa bombe može varirati do 10 kilograma u zavisnosti od modela bombe i vrste eksplozivnog punjenja, ali je ta razlika u izvještavanju zanemarivana.

${ }^{21} \mathrm{~J}$. C. Fitzgerald, '57thbombwing.com', $12^{\text {th }}$ Air Force, 57 $7^{\text {th }}$ Bombardment Wing, 321 $1^{\text {st }}$ Bombardment Group, History: November 154. 1943. dostupno: http://57thbombwing.com/321stHistory/321_ BG_1943-11.pdf, 11.09.2013. (pristupljeno: 28. 4. 2020) 
U izvještaju Narodne zaštite stoji da su napad izvršile 3 grupe po 9 aviona, koji su izbacili 130 bombi od kojih je na zemlji nađeno 97 kratera i da je moguće da su neki krateri zatrpani eksplozijama drugih bombi. Bombe su pale na ulice: Trebevićka, Travnička, Cicin han, Gornji Soukbunar, Mjedenica, Balibegovica, Bistrik, Turbe, Medrese, Pirin Brijeg, Sagrdžije, Kaukčije Abdulah-efendije, Toromanova, Kečina, Ćemrlina, Hrgića. ${ }^{22}$

U izvještaju Trećeg zbornog područja od 2. decembra 1943. o ovom napadu je navedeno:

"U Sarajevu su srušili i oštetili oko 60 zgrada a izključivo građanskom pučanstvu u pretežno muslimanskim četvrtima nanieli težke žrtve. Točan broj žrtava još se ne zna, ali se kreće oko 300 u mrtvim i teže ranjenim. Bombardovanje Sarajeva izvršeno je pri slaboj vidljivosti i magli, a izgleda da su bombe bile namienjene željezničkoj pruzi za Višegrad, postaji Bistrik, zgradi ovog zapovjedništva i zgradi “Konak" gdje je smještena njemačka divizija. (...) Prilikom napadaja zrakoplova na Sarajevo 29. XI. manji zastoj kod postaje Bistrik - Sarajevo radi zasipanja." ${ }^{23}$

MINORS navodi da je u ovom bombardovanju poginulo 98 osoba, a ranjeno 144, te da je 168 kuća srušeno, dok izvještaj Župskog nadzorništva rizničke straže daje broj od 127 poginulih i 198 ranjenih, te 90 porušenih kuća. ${ }^{24}$

Splitske novine Novo doba pišu da je Sarajevo bombardovano 1. decembra 1943. godine, kada je 105 ljudi poginulo, a 155 ranjeno. ${ }^{25}$ Taj napad nije zabilježen ni u jednom zvaničnom izvještaju, te se vjerovatno radi o pogrešno

${ }^{22}$ HAS, KNNZ-12, Kutija 1, Izvještaj o bombardiranju 29. XI 1943, broj 20/44 od 7. I 1944.

23 "Izvještaj zapovjedništva Trećeg zbornog područja od 2. decembra 1943. god. o situaciji u južnom dijelu Bosne i Hercegovne, Izvj. broj: 758/tajno, u Sarajevu, dne 2. prosinca 1943”, u: Zbornik dokumenata i podataka o Narodnooslobodilačkom ratu jugoslovenskih naroda, tom IV, knjiga 20- borbe u Bosni i Hercegovini 1943. godine, dokument br. 215, Beograd: Vojni istorijski institut Jugoslovenske narodne armije, 1959, 715.

${ }^{24}$ Marica Karakaš Obradov, Anglo-američka bombardiranja Hrvatske u Drugom svjetskom ratu: saveznički zračni napadi na Nezavisnu Državu Hrvatsku 1943.-1945, Zagreb: Hrvatski institut za povijest, 2008, 290.

${ }^{25}$ Isto. 
prenesenom podatku o bombardovanju od 29. novembra 1943. godine.

Prvo strateško bombardovanje na području Sarajeva izvedeno je 27. juna 1944. godine. U ovom bombardovanju relativno manjeg obima dva bombardera 15. vazdušnih snaga USAAF-a bacila su 5 tona bombi na aerodrom Rajlovac. ${ }^{26}$ Izvještaj Kotarskog nadzorništva narodne zaštite daje podatak o 41 bačenoj bombi od kojih tri nisu eksplodirale, već su ostale zabijene u tlo, te o napadu lovaca iz pratnje bombama na željeznicu. ${ }^{27} \mathrm{U}$ Izvještaju Operativnog odjela Ministarstva oružanih snaga NDH navedeno je da je bačeno 37 bombi od 250 kilograma oko 500 metara sjeverno od Rajlovca, ${ }^{28}$ pri čemu su oštećene kuće i željeznička pruga. ${ }^{29}$

Prvo bombardovanje grada vazdušnim snagama pod komandom RAF-a izvršeno je 28. jula 1944 godine. Tada je šest lakih bombardera tipa Lockheed Ventura 13. skvadrona Grčkog kraljevskog vazduhoplovstva (RHAF), koji se nalazio u sastavu Bliskoistočne komande RAF-a, izvršilo misiju u kojoj je bačeno 30 bombi od 500 lbs ukupne mase 6,8 tona. Meta napada su bile željezničke radionice, a bombardovanje je izvršeno u 09:05 sati sa visine od 3700 metara. Posade su izvijestile da je snop bombi pao preko radionica, da su direktno pogođene zgrade i da su viđena dva stuba gustog crnog dima kako se dižu. Protivavionska artiljerija je oborila jedan avion, čija posada je iskočila padobranima. ${ }^{30}$

U izvještaju MINORS-a ovaj napad je opisan veoma šturo: “Oko 09:30 sati 6 nepr. zrakoplova-lovaca bombardiralo je Sarajevo. Poginulo je i ranjeno nekoliko vojnika. Šteta je neznatna. Jedan napadački zrakoplov je

${ }^{26}$ G. R. Davis, Bombing the European Axis Powers, CD-ROM, Table 1944-1.

${ }^{27}$ HAS, KNNZ-12, Kutija 1, Izvještaj o zračnom napadaju na Rajlovac, broj: 83/taj od 5. VII 1944.

${ }^{28}$ Nejasno je da li se misli na aerodrom, željezničku stanicu ili samo mjesto.

29 "Izvještaj Operativnog odjela Ministarstva oružanih snaga NDH od 29. juna 1944. o borbama protiv jedinica NOV i POJ na području Dervente, Gornjeg Vakufa i Fojnice, dnevno izviješće Ia broj 181/44 Operativnog odjela Ministarstva oružanih snaga 29. VI 1944", u: Zbornik dokumenata i podataka o Narodnooslobodilačkom ratu jugoslovenskih naroda, tom IV, knjiga 26- borbe u Bosni i Hercegovini 1944. god, dokument br. 151, Beograd: Vojnoistorijski institut, 1967, 561.

${ }^{30}$ The National Archives of United Kingdom (Dalje: The National Archives), Air Ministry and successors: Operations Record Books, Squadrons, Squadron Number: 13 RHAF (Royal Hellenic Air Force) Summary of Events: July 1944, signatura: AIR 27/188/11. 
srušen". ${ }^{31}$ Kotarsko nadzorništvo narodne zaštite detaljnije opisuje ovaj napad i daje podatak da je šest avona bacilo 26 bombi, da su tri pale na Osman-pašinu vojarnu, gdje su pogodile jedan kamion natovaren municijom, dok su 23 bombe pale oko protivavionske baterije na Kovačićima. ${ }^{32}$ Od tih 26 bombi pronađene su tri neeksplodirane, dvije u koritu rijeke Miljacke, a jedna na njenoj desnoj obali. Ni u jednom izvještaju se ne navodi tačan broj žrtava, osim da je nakon bombardovanja njemačka vojska blokirala dio grada oko Kovačića, gdje je bila smještena protivavionska baterija. ${ }^{33}$

Generalni cilj ranih bombardovanja Bosne i Hercegovine bilo je ometanje saobraćaja iz doline rijeke Save prema Jadranskom moru, ${ }^{34}$ a do početka septembra 1944. godine osim lovačko-bombarderskih napada na željeznicu, kolone motornih vozila i aerodrome u okolini Sarajeva, nisu zabilježena bombardovanja samog grada. U septembru 1944. godine počinju žešći vazdušni napadi na područje Bosne i Hercegovine, koji traju do polovine januara 1945. godine. Oni se podudaraju sa napredovanjem Crvene armije i njenim presjecanjem pruge Solun - Beograd, te početkom povlačenja njemačke vojske ka zapadu. Kako bi otežali položaj njemačke vojske smanjenjem njenih manevarskih mogućnosti i razdvajanem jedinica u manje grupe, savezničke vazdušne snage i Narodnooslobodilačka vojska Jugoslavije u prvoj sedmici septembra 1944. godine izvode združenu operaciju 'Ratweek' usmjerenu protiv njemačkih komunikacija i transporta. ${ }^{35}$ Kako su ovom operacijom ciljane komunikacije širom Jugoslavije i Sarajevo je kao regionalno željezničko čvorište između Broda, Mostara i Višegrada postalo strateška meta.

31 "Izvještaj operativnog odjela Ministarstva oružanih snaga NHD od 29. jula 1944 o borbama protiv jedinica NOV i POJ u Bosni i Hercegovini, dnevno izvješće Ia broj 211/44 Operativnog odjela Ministarstva oružanih snaga 29. VII 1944", u: Zbornik dokumenata i podataka o Narodnooslobodilačkom ratu jugoslovenskih naroda, tom IV, knjiga 27- borbe u Bosni i Hercegovini 1944. god, dokument br. 176, Beograd: Vojnoistorijski institut, 1967, 693.

${ }^{32}$ Današnji Kampus Univerziteta u Sarajevu.

${ }^{33}$ HAS, KNNZ-12, Kutija 2, Zračni napadaj na grad Sarajevo dne 28 VII 1944, broj: 107/taj od 28. VII 1944.

${ }^{34}$ Božo Lazarević, Vazduhoplovstvo u NOR-u 1941-1945, Beograd: Vojnoizdavački zavod Vojno delo, 1972, 91.

${ }^{35}$ Fitzroy Mclean, Eastern Approaches, Oxford: Alden Press, 1949, 470-472. 
Šezdeset i devet bombardera B-17 Flying Fortress iz sastava 5. bombarderskog winga 15. vazdušnih snaga USAAF-a, 8. septembra 1944. godine napalo je željezničke instalacije u Sarajevu. Mete napada su bile željeznički most u Starom Hrasnom i željezničke stanice na koje su 301. (336. misija), 463. (99. misija). i 483. (88. misija) bombarderska grupa bacile 184 tone bombi ${ }^{36}$. Grupa 463. je izvijestila da su rezultati bombardovanja bili loši. Analizom aerofoto snimka bombardovanja 301. bombarderske grupe koja je bacila 312 bombi od 500 lbs mase 70,8 tona na Alipašin Most, vidljivo je da je više od polovine bombi promašilo metu, te da je bilo promašaja i od nekoliko kilometara. ${ }^{37}$

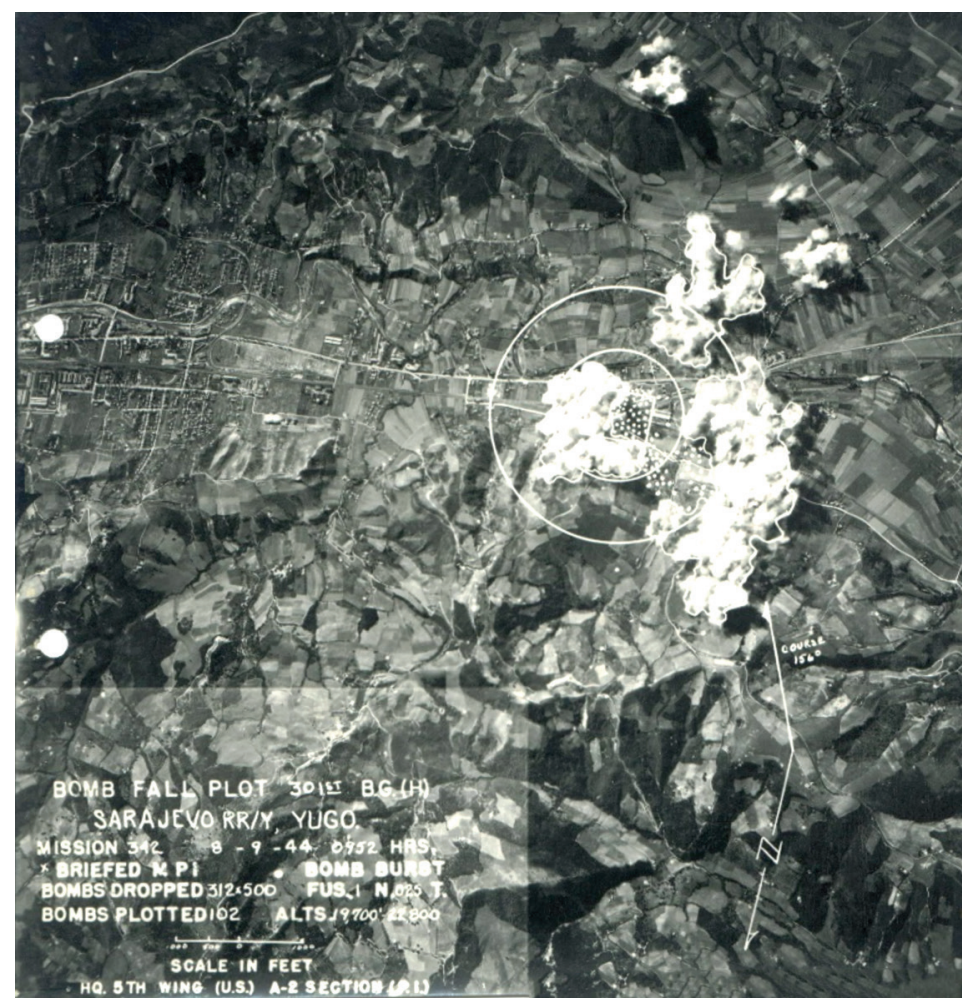

Aerofoto snimak bombardovanja Alipašinog Mosta 9. septembra 1944. godine. Izvor: 301. Bombardment Group Memorial Site https://301bg.com

${ }^{36}$ Richard E. Drain, $5^{\text {th }}$ Bomb Wing-History of Aircraft Assigned. Washington DC: Library of Congress Catalog signatura: D790.D73, 2002, 137.

${ }^{37}$ 301th Bombardment Group (H) Bombing Missions, https://www.301bg.com/WWII_Missions. cfm (pristupljeno: 19. 4. 2020) 
Bombe su pale na željezničku stanicu Alipašin Most i predio Kovačići, te je zbog štete na postrojenjima obustavljen željeznički saobraćaj prema Bosanskom Brodu i Višegradu. Također se kaže da je u ovom napadu poginulo oko 300 osoba, a da je veliki broj ranjen. ${ }^{38} \mathrm{U}$ izvještaju Narodne zaštite navedeno je da je 56 bombardera po lijepom vremenu u dva talasa u 9:50 i 10:20 sati, bacilo 450 bombi od 50 do $250 \mathrm{~kg}$ u okolinu Vraca i na Alipašin Most. ${ }^{39}$ Ovaj napad je izazvao velike žrtve, jer su bombe pogodile naselje Kovačići i izbjeglički logor, koji je bio smješten nedaleko od ranžirne stanice Alipašin Most u kojem su se nalazile izbjeglice iz Istočne Bosne. Nakon raščišćavanja ruševina pronađena su tijela 255 poginulih. Od toga 43\% tijela žrtava (110 osoba, op.a.) pronađeno je u izbjegličkom logoru, a od vatre iz peći prevrnutih prilikom bombardovanja izgorjele su barake u kojima su izbjeglice bile smještene. ${ }^{40}$ Nakon ovog napada u Sarajevu je oko 700 ljudi ostalo bez smještaja, ${ }^{41} 200$ ljudi je sahranjeno u zajedničkoj grobnici, za 66 se navodi da su izgorjeli u barakama, a nepoznat broj je raznesen eksplozijama. ${ }^{42} \mathrm{~S}$ obzirom na broj žrtava dat u bilo kojem od spomenutih izvještaja ili analiza, stradanje u izbjegličkom logoru na Alipašinom Mostu je najveće pojedinačno stradanje od ratnih dejstava na području Sarajeva u dvadesetom stoljeću.

Trinaesti skvadron RHAF-a sada u sastavu BAF-a, vratio se nad Sarajevo 15. i 17. oktobra 1944. godine, prvi put sa 9 aviona kada zbog oblaka nisu uspjeli uočiti cilj, te je skvadron produžio ka alternativnoj meti, a drugi

\footnotetext{
38 "Izvještaj Operativnog odjela Ministarstva oružanih snaga NDH od 9. septembra 1944. o borbi na području Tuzle, dnevno izvješće Ia 254/44 Operativnog odjela Ministarstva oružanih snaga 9. IX 1944", u: Zbornik dokumenata i podataka o Narodnooslobodilačkom ratu jugoslovenskih naroda, tom IV, knjiga 29- borbe u Bosni i Hercegovini 1944. god-septembar, dokument br. 162, Beograd: Vojnoistorijski institut, 1968, 695.

${ }^{39}$ HAS, KNNZ-12, Kutija 2, Izvješće o zračnom napadu na Sarajevo i Ali-pašin Most 8. IX 1944 broj: 156/taj od 21. IX 1944.

${ }^{40}$ Isto.

${ }^{41}$ M. Karakaš Obradov, Anglo-američka bombardiranja Hrvatske u Drugom svjetskom ratu, 291.

${ }^{42}$ Senija Milišić, "U izbjegličkom logoru Alipašin Most ubijeno je više od 200 osoba", STAV, Sarajevo, 24. 8. 2019. dostupno:<https://stav.ba/u-izbjeglickom-logoru-alipasin-most-ubijeno-je-vise-od200-osoba/>24.8.2019. (pristupljeno: 28. 4. 2020)
} 
put sa 12 aviona od kojih je 10 bacilo bombe na ranžirnu stanicu Alipašin Most. Ukupno je bačeno 40 bombi od 500 lbs, odnosno 9 tona. Napad 17. oktobra je izvršen naletom dvije grupe od po 6 aviona od kojih je prva sa visine od 4000 metara snop bombi bacila u središte stanice, te direktno pogodila 4 zgrade nakon čega se gust smeđi dim podigao do oko 900 metara visine. Druga grupa je bombardovala sa 4300 metara i njene bombe su pale oko 200 metara sjeveroistočno od stanice. ${ }^{43} \mathrm{U}$ napadu je poginulo 5 osoba, 4 su ranjene, a navedeno je da je u ovom napadu na Alipašin Most bačeno 10 manjih bombi. ${ }^{44}$ Nakon ovog napada Kotarsko nadzorništvo narodne zaštite uputilo je zahtjev Zapovjedništvu mjesta za osiguranje tri neeksplodirane bombe pronađene između remize motornih kola i glavnog puta Sarajevo - Ilidža. ${ }^{45}$

Izbijanjem Crvene armije na granicu Jugoslavije njemačka Armijska grupa E prisiljena je na povlačenje iz Grčke koje izvršava u oktobru 1944. godine. Već početkom novembra, dijelovi ove grupe armija uz borbu ulaze u Bosnu i Hercegovinu na pravcima Podgorica - Trebinje - Mostar i Prijepolje - Višegrad, a od 15. novembra i štab joj se nalazi u Sarajevu. ${ }^{46}$ U cilju sprječavanja ovog manevra njemačkih snaga, presjecanje željezničke pruge prema Brodu dobija strategijsku važnost, te saveznička ratna vazduhoplovstva izvršavaju bombardersku kampanju na objekte na željezničkoj pruzi Višegrad - Sarajevo - Brod. To je razlog zbog kojeg se tokom novembra 1944. godine u Sarajevu dešavaju najteža bombardovanja tokom Drugog svjetskog rata. Petnaeste vazdušne snage USAAF-a i 205. bombarderska grupa RAF-a na

${ }^{43}$ The National Archives, Air Ministry and successors: Operations Record Books, signatura: AIR 27/188/19.

44 "Izvještaj zapovjedništva Glavnog stožera domobranstva od 18. oktobra 1944. o dejstvima protiv jedinica NOVJ kod Slavonskog Broda, Koprivnice, u Gorskom Kotaru i o napuštanju Poljane i Međurića, dnevno izvješće Ia broj 292/44 Operativnog odjela Ministarstva oružanih snaga 18. X 1944", u: Zbornik dokumenata i podataka o Narodnooslobodilačkom ratu jugoslovenskih naroda, tom V, knjiga 34- borbe u Hrvatskoj 1944. god. novembar, dokument br. 139, Beograd: Vojnoistorijski institut, 1966, 681.

${ }^{45}$ HAS, KNNZ-12, Kutija 2, Zahtjev za osiguranje nerasprsnutih bombi broj: 1281/taj od 23. X 1944.

${ }^{46}$ Zbornik dokumenata i podataka o Narodnooslobodilačkom ratu naroda Jugoslavije, dokumenti Njamačkog rajha 1944-1945, tom XII, knjiga 4, Beograd: Vojnoistorijski institut, 1979, 708. 
Sarajevo su poslale 8 misija od kojih su dvije otkazane zbog lošeg vremena, a u jednoj je bačena samo jedna bomba. Na grad je tokom ovog mjeseca bačeno ukupno 721 tona bombi mase od 250 do 4000 lbs.

Prvi novembarski napad izvršilo je 19 aviona 205. bombarderske grupe RAF i to 8 aviona tipa Welington Mk.X iz 37. i 104. skvadrona, 8 tipa Halifax Mk.II i 3 tipa Liberator Mk.VI-pathfindera iz 614. skvadrona, ${ }^{47} \mathrm{u}$ noći između 4. i 5. novembra na ranžirnu stanicu Alipašin Most. Područje je identificirano navigacionim uređajem "GEE", ${ }^{48}$ a grad i rijeka vizualno. Osvjetljavajuće baklje su izbačene u 00:25 sati iznad područja mete uz vizualnu orijentaciju prema rijeci Miljacki, ali je nišanska tačka bila zaklonjena oblacima. ${ }^{49}$ Zbog loše vidljivosti i naredbe da ne bombarduju grad, samo jedan avion iz 104. skvadrona je izbacio bombu HC4000 mase $4000 \mathrm{lbs}, 1,8$ tona, ali nije viđena eksplozija. ${ }^{50}$ Prema izvještaju Glavnostožernog ureda Ministarstva oružanih snaga oko 00:30 sati 5. novembra bačeno je mnogo svijetlećih raketa oko Butmira, a zatim je oko 00:40 sati zapadno odatle spušten padobranski desant. ${ }^{51} \mathrm{Ni}$ ovaj izvještaj ne spominje eksploziju. Zvanično ovo je bio jedini noćni napad na Sarajevo. Padobranski desant koji se navodi je vjerovatno bilo dostavljanje vojne pomoći snagama NOVJ-a, koje je te noći izvršio dio 104 . skvadrona. ${ }^{52}$

\footnotetext{
${ }^{47}$ Pathfinderi su bili skvadroni ili pojedini avioni koji su formaciju bombardera navodili na cilj, te ga osvjetljavali bakljama ili označavali markerima meta radi preciznijeg bombardovanja.

${ }^{48}$ Sistem navigacije pomoću radio valova emitovanih sa zemlje.

${ }^{49}$ The National Archives, Air Ministry and successors: Operations Record Books, signatura: AIR 27/2121/19.

${ }^{50}$ The National Archives, Air Ministry and successors: Operations Record Books, signatura: AIR 27/822/22.

51 "Izvještaj Glavnostožernog ureda Ministarstva oružanih snaga NDH od 5. novembra 1944. o borbama na sektoru Banja Luke i Rogatice i o stanju u 9. Posadnom zdrugu, dnevno izvješće Ia broj 310/44 Glavnostožernog ureda Ministarstva oružanih snaga 5. XI 1944", u: Zbornik dokumenata i podataka o Narodnooslobodilačkom ratu jugoslovenskih naroda, tom IV, knjiga 30borbe u Bosni i Hercegovini 1944, dokument br. 161, Beograd: Vojnoistorijski institut, 1968, 889.

52 The National Archives, Air Ministry and successors: Operations Record Books, signatura: AIR $27 / 822 / 22$.
} 
Napad je ponovljen po danu 5. novembra. Na Sarajevo je poslano 18 aviona i to 7 tipa Halifax i 3 tipa Liberator, od kojih su se dva vratila ranije zbog kvarova, iz 614. skvadrona, 3 tipa Wellington Mk.X iz 40. skvadrona i 5 tipa Wellington Mk.X iz 104. skvadrona. Ukupno je u napadu bačeno 30,8 tona bombi od čega je 614. skvadron bacio 63 bombe od $1000 \mathrm{lbs}$ sa visine 5500 metara oko 16:40 sati, nakon što su dva aviona ovog skvadrona markerima pogodili središte ranžirne stanice i označili metu. Posade su prijavile da su nakon bombardovanja uočile vatre na području mete. ${ }^{53}$ Četrdeseti skvadron je bombardovao sa 4600 metara, te jednom bombom od $4000 \mathrm{lbs}$ pogodio metu označenu markerima. Drugi avion je nišanio vizualno i nije osmotrio rezultat, a treći nije uspio identifikovati metu, te nije bacio bombu. ${ }^{54}$ Pet bombi od $4000 \mathrm{lbs}$ bacio je 104. skvadron zapadno od mjesta na koje je pogođeno markerima, ali rezultati nisu osmotreni i posade su izvijestile da smatraju da su bombe razbacane oko mete. ${ }^{55}$ U izvještaju Narodne zaštite navodi se da su u ovom napadu pogođeni Alipašin Most, Švrakino Selo, Dolac- Kolonija i Pofalići. ${ }^{56}$

Na ranžirnu stanicu Alipašin Most Sarajevo 6. novembra upućeni su bombarderi 47. i 49. bombarderskog winga, 15. vazdušnih snaga USAAF-a, ali napad nije izvršen zbog oblaka koji su zaklonili metu, a avioni su se vratili u bazu. ${ }^{57}$

Narednog dana, 7. novembra Sarajevo je napadnuto dva puta i pretrpilo je najteže bombardovanje tokom Drugog svjetskog rata. Prvi napad su izvršili bombarderi 451. bombarderske grupe (147. misija), 461. bombarderske

${ }^{53}$ The National Archives, Air Ministry and successors: Operations Record Books, signatura: AIR 27/2121/19.

${ }^{54}$ The National Archives, Air Ministry and successors: Operations Record Books, signatura: AIR 27/413/21.

55 The National Archives, Air Ministry and successors: Operations Record Books, signatura: AIR 27/822/22.

${ }^{56}$ HAS, KNNZ-12, Kutija 2, Izvješće o napadu od 5 studenog, broj: 168/taj od dana 9. XI 1944.

${ }^{57}$ Air Force Historical Research Agency, Maxwell AFB (Dalje: AFHRA), Archived Air Force Publications and Forms, Headquarters $449^{\text {th }}$ Bombardment Group Special Narrative Report No.159 6 November 1944, rolna: BO582, okvir 797. 
grupe (130. misija) i 484. bombarderske grupe (110. misija) iz sastava 49. bombarderskog winga USAAF-a sa 82 aviona B-24 Liberator, ${ }^{58}$ a drugi 31. i 34. skvadron SAAF, 37, 40, 70, 104. i 178. skvadron iz 205. grupe RAF-a sa 85 aviona. ${ }^{59}$ Ukupno je na Sarajevo tog dana bačeno 453 tone bombi što je $62 \%$ tonaže bačene u novembru 1944. godine, odnosno $46 \%$ ukupne tonaže koju su saveznici bacili na grad tokom Drugog svjetskog rata.

USAAF je napad izvršio sa 82 aviona u tri vala sa visina od 6100, 6400 i 6700 metara. Meta je bila ranžirna stanica Alipašin Most na koju je bačeno 167,8 tona bombi od 500 lbs. Posade 461. grupe su izvjestile da je bombardovanje vršeno vizualno, ali da su avioni gotovo potpuno promašili metu. ${ }^{60} \mathrm{U}$ izvještaju 484. grupe stoji da je bombardovano vizualno kroz rupu u oblacima i da su bombe djelimično prebacile metu, ali da je načinjeno prilično štete. ${ }^{61}$ Ukupan rezultat bombardovanja 49. winga je bio uspješan, jer je uništena većina radionica i 6 lokomotiva, a stanične instalacije teško oštećene. ${ }^{62} \mathrm{U}$ naletu američkih aviona bombe su pale na ulice Ilidžanska i Gračanska, te na dijelove grada Kolonija Dolac, Alipašin Most i Švrakino Selo. ${ }^{63}$

Kraljevsko ratno vazduhoplovstvo je napad izvršilo u periodu od 15:30 do 15:50 sati u kojem je 85 aviona bacilo 300,7 tona bombi, što je sa $31 \%$ ukupne tonaže bombi bačene na grad najteži pojedinačni napad. Sa 10 Welingtona Mk.X bombardovao je 37. skvadron sa visine od 3600-4300 metara u 15:30 sati, te je bacio 1 bombu od 4000 lbs, 76 bombi od 500 lbs (8 sa usporenjem od 6 sati i 7 sa usporenjem od 12 sati) i 68 od 250 lbs. Posade su po povratku s misije izvjestile da su preciznost bombardovanja i koncentracija pogodaka bile ispod prosjeka, te da je primijećeno kako

${ }^{58}$ The Fifteenth Air Force. 2018. https://15thaf.org/49th_BW/Missions/November\%201944/PDFs/ Op_Ord_242.pdf (pristupljeno: 28. 4. 2020)

${ }^{59}$ R. G. Davis, Bombing the European Axis Powers, CD-ROM, Table 1944-2.

${ }^{60}$ https://461st.org, Missions, November 1944, https://461st.org/Missions/November1944.html, 06.3.2020, (pristupljeno: 28. 4. 2020)

${ }^{61}$ http://484th.org, Missions, November 1944, https://484th.org/Missions/November_1944.html, 11.02.2018. (pristupljeno: 28. 4. 2020)

${ }^{62}$ Jesse Pettey, One More Mission, Bloomington: Xlbss, 2001, 324.

${ }^{63}$ HAS, KNNZ-12, Kutija 2, Izvješće o zračnom napadu 07. XI 1944 broj: 152/taj od 13. XI 1944. 
su neke bombe zalutale. Jedan avion ovog skvadrona je oboren u napadu, a jedan se zapalio pri slijetanju. ${ }^{64}$ Četrdeseti skvadron je bombardovao sa 12 Welingtona Mk.X metu Istočna željeznička stanica ${ }^{65}$ oko $15: 30$ sati bombama od 250 i 500 lbs. Posade su izvijestile da su tri aviona bombe bacili sjeverno od mete, ali da je bombardovanje uglavnom bilo precizno i da je glavnina bombi pala na zapadni kraj željezničke stanice pored željezničke skretnice u obliku potkovice. ${ }^{66}$ Sa dvadeset aviona Welington Mk.X 70. skvadron je izvršio bombardovanje sa visina između 3000 i 4200 metara, od 15:30 do 15:48 sati pri čemu je bacio 174 bombe od 500 lbs (39 sa usporenjem od 6 i 12 sati) i 154 bombe od 250 lbs. Prema izvještajima posada preciznost i koncentracija bombi su bili osrednji i dio bombi je pao sjeverno, istočno i južno od stanice. ${ }^{67}$ Napad 104. skvadrona izvršen je sa 8 aviona Welington Mk.X koji su bacili 3 bombe od 4000 lbs, 54 bombe od 500 lbs (tri sa usporenjem), 54 bombe od 250 lbs (dvije sa usporenjem). Prema izvještajima bombe su pale na istočni kraj ciljanog prostora, a preciznost je bila solidna uprkos gustom dimu. ${ }^{68}$ Sa 12 aviona Liberator sa visine 4800-5200 metara u 15:30 178. skvadron je izvršio napad pri čemu je bacio 88 bombi od 1000 lbs i 4 bombe od 2000 lbs. Dio bombi je pogodio područje kod zapadne skretnice, manji dio je pao sjeverno i južno od stanice, a dio je viđen kako pada na grad. ${ }^{69}$ Napad 31. skvadrona SAAF-a izveden je sa 11 aviona Liberator sa visine od 5500 do 6100 metara i pri tom bacio 126 bombi od 1000 lbs. U izvještaju stoji da je pogođen zapadni

${ }^{64}$ The National Archives, Air Ministry and successors: Operations Record Books, signatura: AIR 27/392/22.

${ }^{65}$ Željeznička stanica uskog kolosjeka koja se nalazila na Pofalićima i željezničke skretnice koje su se nalazile na Dolac Malti.

${ }^{66}$ The National Archives, Air Ministry and successors: Operations Record Books, signatura: AIR 27/413/21.

${ }^{67}$ The National Archives, Air Ministry and successors: Operations Record Books, signatura: AIR 27/617/21.

${ }^{68}$ The National Archives, Air Ministry and successors: Operations Record Books, signatura: AIR 27/822/22.

${ }^{69}$ The National Archives, Air Ministry and successors: Operations Record Books, signatura: AIR 27/1121/3. 
dio stanice, iako svi pogoci nisu osmotreni zbog dima i izmaglice. ${ }^{70}$ Sa 12 aviona Liberator Mk.IV 34. skvadron SAAF je bombardovao sa visine od 5800 do 6000 metara u 15:40 sati i bacio 128 bombi od 1000 lbs. Posade su izvjestile da su osmotrile pogotke bombi na dijelu stanice bliže gradu. ${ }^{71}$ Sve posade koje su sudjelovale u ovom napadu izvijestile su da su mete identifikovale i napale vizualno.

Prema izvještaju Zapovjedništva zračne odbrane Sarajeva od 9. novembra 1944. koji se nalazi kao prilog izvještaju Kotarskog nadzorništva narodne zaštite, prvi napad izveden je pravolinijski u 12:47 sati, a drugi napad u kružnom letu u 15:22 sati kad su avioni pojedinačno gađali ciljeve. ${ }^{72}$

Bombe iz drugog napada 7. novembra prema izvještaju Kotarskog nadzorništva narodne zaštite pale su na željezničku stanicu (u današnjoj Kolodvorskoj ulici, op.a.), ulice Hakije Hadžića, Fra Jukića (današnja Danijela Ozme), Husein-kapetana, Mažuranića, Skenderije, Donjeg Soukbunara, Zagriće, Čobanije. ${ }^{73}$

U dnevnom izvještaju Glavnostožernog ureda Ministarstva oružanih snaga od 9. novembra 1944. o ovom napadu se kaže:

"Oko 1300 sati 140 nepr. zrakoplova napalo je Sarajevo u 3 vala, a oko 16.00 sati istog dana 128 nepr. zrakoplova ponovilo je napadaj. ${ }^{74}$ Pogođeni su: Alipašin Most gdje su srušena 2 želj. mosta, želj. postaja i želj. uređaji, stožer 3. zrakoplovnog područja, okolica vojničke bolnice, Čengić Vila, Novo Sarajevo, Švrakino Selo, gradska plinara, Kolonija Dolac, gradska Bratinska blagajna s punim pogodkom i više posebničkih zgrada. Štete i žrtve su znatne." ${ }^{75}$

${ }^{70}$ The National Archives, Air Ministry and successors: Operations Record Books, signatura: AIR 27/358/3.

${ }^{71}$ The National Archives, Air Ministry and successors: Operations Record Books, signatura: AIR 27/377/5.

${ }^{72}$ HAS, KNNZ-12, Kutija 2, Izvješće o zračnom napadu 07 XI 1944 broj: 152/taj od 13. XI 1944.

${ }^{73}$ Isto.

${ }^{74}$ Veći broj aviona u izvještaju MINORS-a je zbog činjenice da je izbrojana i lovačka pratnja, tako je u prvom napadu ukupan broj aviona bio 130 .

${ }^{75}$ Izvještaj Glavnostožernog ureda Ministarstva oružanih snaga NDH od 9. novembra 1944. o napadu jedinica NOVJ na Donju Zelinu i otok Cres, o borbama u Dalmaciji i u Hrvatskom 


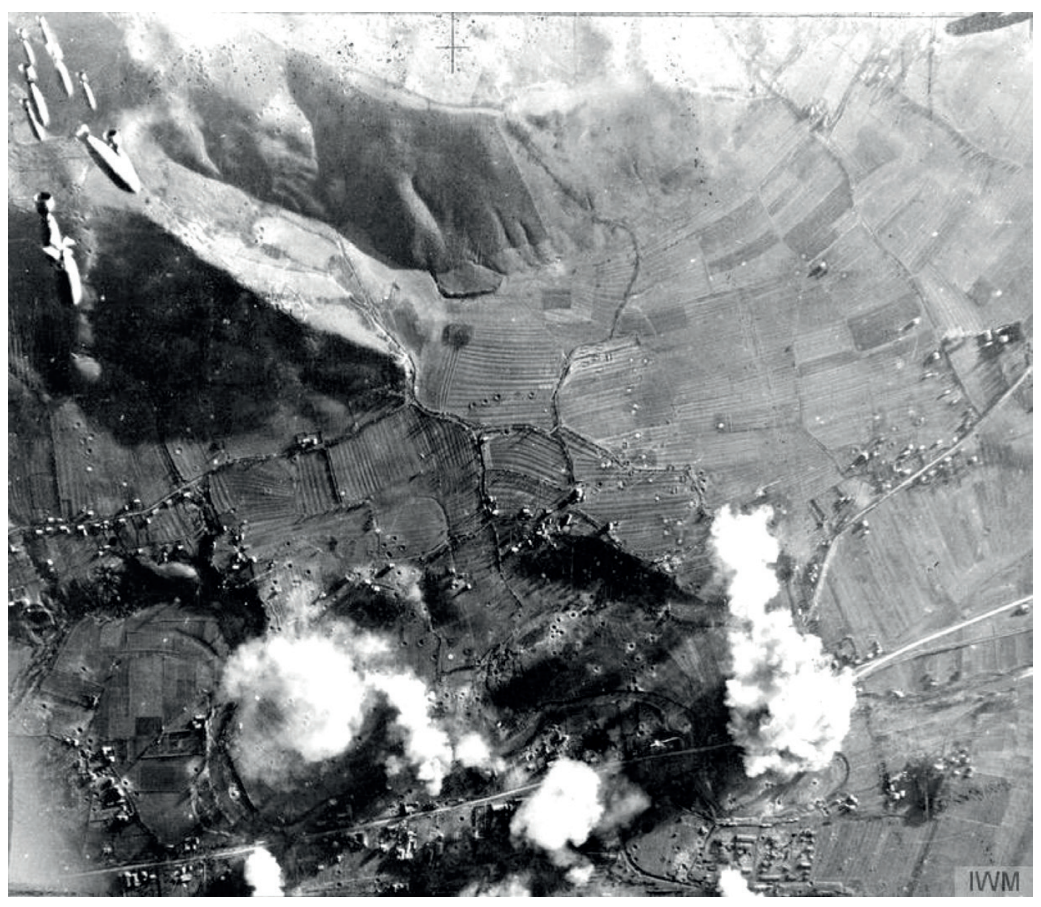

Aerofoto snimak britanskog bombardovanja Alipašinog Mosta. Izvor: Imperial War Museum

Za napade od 7. novembra navedeni su različiti brojevi poginulih i ranjenih. U izvještaju MINORS-a od 11. novembra 1944. godine dat je broj od 253 poginula, 130 ranjenih koji su tražili ljekarsku pomoć i 180 srušenih kuća. ${ }^{76}$ Izvještaj Kotarskog nadzorništva narodne zaštite od 13. novembra navodi 300 poginulih i 220 ranjenih. Samo u podrumu zgrade Bratinske

Zagorju, dnevno izvješće Glavnostožernog ureda Ministarstva oružanih snaga 9. XI 1944, u: Zbornik dokumenata i podataka o Narodnooslobodilačkom ratu jugoslovenskih naroda, tom V, knjiga 35- borbe u Hrvatskoj 1944. god. novembar, dokument br. 141, Beograd: Vojnoistorijski institut, 1967, 685 .

76 "Izvještaj Operativnog odjela Ministarstva oružanih snaga NDH od 11. novembra 1944. o ulasku jedinica NOVJ u Cazin, o borbama na području Knina, Varaždina, Slavonskog Broda i u Gornjem Kotorskom, dnevno izvješće Ia broj 316/44 Operativnog odjela Ministarstva oružanih snaga 11. XI 1944", u: Zbornik dokumenata i podataka o Narodnooslobodilačkom ratu jugoslovenskih naroda, tom V, knjiga 35- borbe u Hrvatskoj 1944. god. novembar, dokument br. 124, Beograd: Vojnoistorijski institut, 1967, 694. 
blagajne (današnja ulica Danijela Ozme), u kojem je eksplodirala bomba nakon što je probila krov i 4 sprata, identifikovani su ostaci 78 žrtava, ali se smatra da je nepoznat broj ljudi potpuno raznesen. ${ }^{77}$ Tokom tri dana nakon napada pronađene su neeksplodirane bombe u zgradi na Soukbunaru br. 27, u Ulici Radne službe- Mrakuša, na Điđikovcu u Hirščovoj bašči, u Nuzurovoj ulici br. 6, u Starčevićevoj br. 23, u Starom Hrasnom br. 26, u Kranjčevićevoj pred Vojnom bolnicom i na Muzeđijinom zemljištu, a na dan napada su naknadno eksplodirale bombe u Ulici Husein-kapetana i Fra Jukića oko 2324 sata. ${ }^{78}$ Neeksplodirane bombe su pronađene i u Radničkoj ulici broj 2, u Kovačićima pred mitnicom u Zagrebačkoj ulici, u Starom Hrasnom br. 13, na livadi braće Muzeđije preko puta Ilidžanske postaje, u Ulici Alibega Firduza kraj Berze rada u dvorištu, ${ }^{79} \mathrm{u}$ Rudarskoj direkciji kod Bratinske blagajne (u zgradi), u Ulici Husein- kapetana br. 65, u Ulici Hadži-Idriza br. 9. ${ }^{80}$

Novi napad 205. bombarderske grupe Kraljevskih zračnih snaga na Alipašin Most u kojem je bačeno 170 tona bombi uslijedio je 18. novembra. U napadu je 614. skvadron sudjelovao sa dva aviona Halifax od kojih je jedan u 14:57 sati označio metu crvenim markerima, koji su pali na sjeverni i sjeverozapadni dio stanice. Drugi je 10 bombi koncentrisao u markirano područje, te pogodio željezničku skretnicu. ${ }^{81} \mathrm{Sa}$ dva aviona je bombardovao 37. skvadron od kojih je svaki nosio po jednu bombu od 4000 lbs. Eksplozije su viđene na južnom i jugozapadnom dijelu ranžirne stanice..$^{82}$ Skvadron broj 178. bombardovao je sa 15 aviona sa visine od 4200 do 4900 metara koji su bacili 80 bombi od $1000 \mathrm{lbs}$ i četiri bombe od $2000 \mathrm{lbs} .{ }^{83} \mathrm{Sa} 3$ aviona

\footnotetext{
${ }^{77}$ HAS, KNNZ-12, Kutija 2, Izvješće o zračnom napadu 07. XI 1944 broj: 152/taj od 13. XI 1944.

${ }^{78}$ HAS, KNNZ-12, Kutija 2, Uklanjanje neeksplodiranih bombi broj: 1247/taj od 8. XI 1944.

${ }^{79}$ HAS, KNNZ-12, Kutija 2, Uništavanje neeksplodiranih bombi broj: 1256/taj od 9. XI 1944.

${ }^{80}$ HAS, KNNZ-12, Kutija 2, Uništavanje neeksplodiranih bombi broj: 1294/taj od 10. XI 1944.

${ }^{81}$ The National Archives, Air Ministry and successors: Operations Record Books, signatura: AIR 27/2121/19.

${ }^{82}$ The National Archives, Air Ministry and successors: Operations Record Books, signatura: AIR 27/392/22.

${ }^{83}$ The National Archives, Air Ministry and successors: Operations Record Books, signatura: AIR 27/1120/18.
} 
i 3 bombe od 4000 lbs je bombardovao 104. skvadron. Prema izvještaju posada samo je jedna eksplozija osmotrena oko 300 metara od nišanske tačke, a druge nisu zbog velikog broja bombi koje su eksplodirale na tlu i gustog dima, jer je bombrdovanje vršeno u isto vrijeme sa avionima 178. skvadrona. Također je raportirano da je jedan snop bombi iz Liberatora promašio metu za oko 5 kilometara. ${ }^{84}$ Jednim avionom i bombom od 4000 lbs, kojom je nišanio u centar ranžirne stanice napao je 40. skvadron, ali je pogodak podbacio. ${ }^{85}$ Sa 12 aviona bombardovao je 34. skvadron SAAF-a sa visine od 5500 do 5700 metara i bacio 120 bombi od 1000 lbs. Raportirano je da su bombe pale u područje mete. ${ }^{86} \mathrm{U}$ napadu su uništeni svi kolosjeci, stanična zgrada i uređaji, ${ }^{87}$ te je srušeno 5 kuća i bilo je ranjenih. ${ }^{88}$

Izvještaj od 19. novembra 1944. Glavnostožernog ureda Ministarstva oružanih snaga navodi da su 34 četveromotorna aviona tog dana ponovo bacili bombe na Alipašin Most. U izvještajima bombarderskih grupa i eskadrila četveromotornih aviona iz 15. zračnih snaga USAAF-a i 205. bombarderske grupe RAF-a ne spominje se napad na Sarajevo pod ovim datumom. Na području Jugoslavije tog dana su napadnuti Maribor, Sisak, Višegrad, Novi Pazar, Podgorica i Sjenica. Prva dva grada su napali

${ }^{84}$ The National Archives, Air Ministry and successors: Operations Record Books, signatura: AIR 27/822/2.

${ }^{85}$ The National Archives, Air Ministry and successors: Operations Record Books, signatura: AIR 27/413/21.

${ }^{86}$ The National Archives, Air Ministry and successors: Operations Record Books, signatura: AIR 27/377/5.

87 “Izvještaj Operativnog odjela Ministarstva oružanih snaga NDH od 19. novembra 1944. o napadu jedinica NOVJ na Peteranec, Uncane, Dobro Selo i Doljanje i o borbama u Slavonskoj Požegi i Pleterni, dnevno izvješće Ia broj 324/44, Operativnog odjela Ministarstva oružanih snaga 19. XI 1944", u: Zbornik dokumenata i podataka o Narodnooslobodilačkom ratu jugoslovenskih naroda, tom V, knjiga 35- borbe u Hrvatskoj 1944. god. novembar, dokument br. 141, Beograd: Vojnoistorijski institut, 1967, 722.

88 "Izvještaj Operativnog odjela Ministarstva oružanih snaga NDH od 21. novebra 1944 o borbama kod Širokog Brijega, Križevaca i Kiseljaka, dnevno izvješće Ia broj 326/44 Operativnog odjela Ministarstva oružanih snaga", u: Zbornik dokumenata i podataka o Narodnooslobodilačkom ratu jugoslovenskih naroda, tom V, knjiga 35- borbe u Hrvatskoj 1944. god-novembar, dokument br. 135, Beograd: Vojnoistorijski institut, 1967, 727. 
bombarderi USAAF-a, a ostale RAF. ${ }^{89}$

Alipašin Most je bombardovan 20. novembra 1944. godine. 25 od 26 bombardera B-24 Liberator 449. bombarderske grupe USAAF u 170. misiji ove grupe, bacilo je 224 bombe od 500 lbs ukupne mase 50,7 tona, od čega je 50 bombi bilo sa usporenjem od 6 do 72 sata, na ranžirnu stanicu Alipašin Most. Bombardovanje je izvršeno sa visine od 6700 metara. Posade su vizualno osmotrile pogotke u zgrade u krugu ranžirne stanice, te pogotke lijevo (južno, op.a.) u prugu koja izlazi iz stanice (prema Mostaru, op.a.). Od toga $43 \%$ bombi je palo u radijusu od 300 metara od nišanske tačke, ${ }^{90} \mathrm{a}$ eksplozije su osmotrene do 1000 metara zapadno od stanice. ${ }^{91}$

Prema izvještaju Kotarskog nadzorništva narodnezaštite od 21. novembra bombe su pale na Alipašin Most, Vraca i selo Kovači pod Igmanom. ${ }^{92} \mathrm{U}$ izvještaju MINORS-a od istog dana stoji: "20. XI između 11:19 i 11:35 sati 50 nepr. bombardera u više valova ponovno su napali okolicu Sarajeva, Alipašin Most, Butmir, okolicu Rajlovca i područje Igmana. Na Sarajevo bačeno je 15 bombi od $500 \mathrm{~kg}$. Srušene su 2 kuće. Žrtve nisu ustanovljene. Protuzrakopl. obrana oborila je 3 napadačka zrakoplova". ${ }^{93}$

Dio izvještaja o oborenim avionima nije tačan, jer 449. grupa nije izgubila nijedan avion tog dana, niti je izgubila ijedan nad Sarajevom. Ova grupa je iznad Bosne i Hercegovine izgubila dva aviona u napadu na Mostar 14. januara 1944. godine i jedan avion u napadu na Bosanski Brod 23. novembra 1944. godine. ${ }^{94}$

${ }^{89}$ G. R. Davis, Bombing the European Axis Powers, CD-ROM, Table 1944-2.

${ }^{90}$ Tri stotine metara ili hiljadu stopa je područje bombarderskog cilja kakvo je definisao USAAF. Pad bombe u to područje je smatran pogotkom.

${ }^{91}$ AFHRA, Archived Air Force Publications and Forms, rolna BO583, okvir 668.

${ }^{92}$ HAS, KNNZ-12, Kutija 2, Izvješće o zračnom napadu dne 20 XI 1944 broj: 1371/taj od 21. XI 44.

93 "Izvještaj Operativnog odjela Ministarstva oružanih snaga NDH od 21. novembra 1944. o borbama kod Širokog Brijega, Križevaca i Kiseljaka, dnevno izvješće Ia broj 326/44 Operativnog odjela Ministarstva oružanih snaga 21. XI 1944", u: Zbornik dokumenata i podataka o Narodnooslobodilačkom ratu jugoslovenskih naroda, tom V, knjiga 35- borbe u Hrvatskoj 1944. godine- novembar, dokument br. 135, Beograd: Vojnoistorijski institut, 1967, 728.

${ }^{94}$ 449th Bomb Group WWII, Aircraft Lost. 2019. <https://449th.com/aircraft-lost/> (pristupljeno: 29. 4. 2020) 
Nakon napada od 18. i 20. novembra Narodna zaštita je od Oružnotehničkog zavoda Oružanih snaga tražila uklanjanje neeksplodiranih bombi na Vracama pokraj reflektora protivavionske odbrane, gdje su pronađena tri komada ${ }^{95}$ te u ulicama Ilidžanska br. 14 , Butmirska br. 18. i Marulića br. $12 .{ }^{96}$

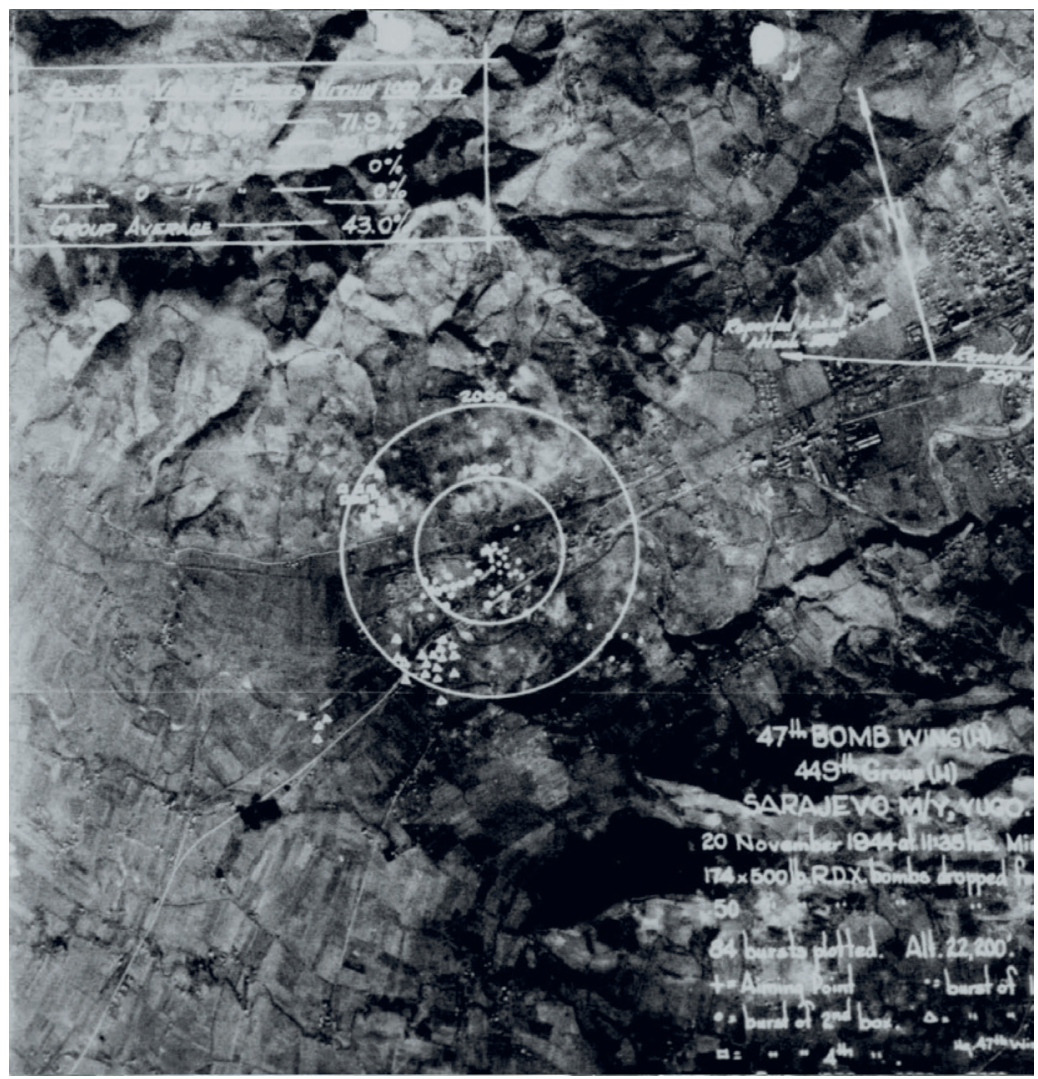

Aerofoto snimak bombardovanja Alipašinog Mosta 20. novembra 1944. Izvor: AFHRA Maxwell AFB.

Dan kasnije, 21. novembra, 24 aviona 499. bombarderske grupe ponovo je poletjelo na bombardovanje Sarajeva u 171. misiji grupe, ali su se vratili zbog gustih oblaka koji su zaklonili metu. ${ }^{97}$

${ }^{95}$ HAS, KNNZ-12, Kutija 2, Uništavanje neeksplodranih bombi broj: 1370/taj od 21. XI 1944.

${ }^{96}$ HAS, KNNZ-12, Kutija 2, Uništavanje neeksplodranih bombi broj: 1418/taj od 4. XII 1944.

${ }^{97}$ AFHRA, Archived Air Force Publications and Forms, rolna BO583, okvir 813. 
Posljednji strateški napad na Sarajevo izvršilo je 12 aviona 205. bombarderske grupe RAF-a, 19. decembra 1944. u kojem su bacili 21,7 tona na metu Istočna željeznička stanica. Iako se napad vodi kao dnevni, bombardovanje je izvršeno u 17:30 sati, kada je nad Sarajevom mrak, pa je nišanjenje vršeno pomoću "GEE” navigacionog uređaja. Ovo je jedini napad na Sarajevo u kojem je nišanjeno tom metodom. Skvadron 614. je predvodio napad i locirao metu pomoću "GEE" navigacionog uređaja, te sa visine od 3700 metara nad metom izbacio osvjetljavajuće baklje. Zbog gustih oblaka posade nisu uspjele locirati metu vizualno, te su odustale od bombardovanja. ${ }^{98}$ Jednim avionom Liberator Mk.IV napao je 37. skvadron, ali zbog oblaka nije vidio metu i bombe je odbacio u more na povratku u bazu. ${ }^{99}$ Skvadron 31. SAAF-a je u misiju poletio sa 11 aviona i 88 bombi od 500 lbs od kojih je 6 bacilo 48 bombi kroz oblake nišaneći u svjetlost baklji koje je bacio 614. skvadron. ${ }^{100}$ Bombe su pale na Hrasno, sjeverni dio Koševa, Alipašin Most i jedna na Osman-pašinu vojarnu. Ranjena su 4 domobrana. ${ }^{101}$ Nakon ovog napada Kotarsko nadzorništvo narodne zaštite je prijavilo 11 neeksplodiranih bombi, 8 u Hrasnom kod kuće Knjažević Riste $^{102}$ i tri na Vracama. ${ }^{103}$

98 The National Archives, Air Ministry and successors: Operations Record Books, signatura: AIR $27 / 2121 / 21$.

${ }_{99}$ The National Archives, Air Ministry and successors: Operations Record Books, signatura: AIR 27/392/33.

100 The National Archives, Air Ministry and successors: Operations Record Books, signatura: AIR $27 / 358 / 4$.

101 "Izvještaj Glavnog stožera Ministarstva oružanih snaga NDH od 28. decembra 1944. o stanju na području Banja Luke, Sarajeva i u dolini Drine, dnevno izvješće Ia broj 363/44 Glavnog stožera Ministarstva oružanih snaga 28. XII 1944", u: Zbornik dokumenata i podataka o Narodnooslobodilačkom ratu jugoslovenskih naroda, tom IV, knjiga 31- borbe u Bosni i Hercegovini 1944. godine, dokument br. 179, Beograd: Vojnoistorijski institut, 1968, 868.

${ }^{102}$ HAS, KNNZ-12, Kutija 3, Uništavanje neeksplodranih bombi broj: 1465/taj od 21. XII 1944.

${ }^{103}$ HAS, KNNZ-12, Kutija 3, Uništavanje neeksplodranih bombi broj: 1458/taj od 20. XII 1944. 


\section{Zaključak}

Dejstva njemačke avijacije nad Sarajevom su bila relativno kratkotrajna i imala su dva cilja: onesposobljavanje jugoslovenskih vazdušnih snaga za efektivna dejstva protiv jedinica Wehrmachta i bombardovanje gradskog područja Sarajeva. Prvi je ostvaren napadom na aerodrom Jugoslovenskog kraljevskog ratnog vazduhoplovstva Rajlovac i na njemu stacionirane snage, a drugi napadom na ciljeve koji nisu bili validni u strogo vojnom smislu. Njemački napadi od 12. i 13. aprila 1941. godine bili su prvi bombarderski napadi na grad Sarajevo i jedini napadi koji su ciljali gradsko područje i stanovništvo.

Glavna meta savezničkih napada na području Sarajeva, kako po broju operativnih letova tako i po količini bačenih bombi bila je željeznica. Na području Sarajeva i okoline izvršeno je 10 misija strategijske avijacije, 5 od strane USAAF-a i 5 od strane RAF-a, pri čemu u dvije misije USAAF-a nisu bačene bombe. Strategijska avijacija izvršila je 293 efektivna borbena ${ }^{104}$ leta u kojim je na grad bačena 931 tona bombi. Taktički (laki i srednji) bombarderi su izvršili 5 misija, 2 USAAF, a 3 RAF, od čega u jednoj misiji RAF-a nisu bačene bombe. Taktička avijacija je bombardovanje Sarajeva izvršila sa 45 efektivnih borbenih letova i bacila 53,4 tone bombi.

Od ukupno 15 savezničkih bombarderskih misija, 14 je bilo usmjereno na željeznicu na koju je bačeno 979,4 od ukupno 984,4 tona bombi, odnosno 99,5\% ukupne tonaže. Jednoj bombarderskoj misiji strategijske avijacije sa dva efektivna borbena leta u kojoj je bačeno 5 tona bombi, odnosno 0,5\% ukupne tonaže, meta je bio aerodrom Rajlovac. Osam strategijskih misija, od kojih 6 efektivnih, izvršeno je u novembru 1944. godine i u njima su bačene gotovo tri četvrtine ukupne tonaže bombi bačenih na grad, odnosno 721 tona, a gotovo polovina u dvije misije 7 . novembra.

Poredimo li ukupnu količinu bombi bačenih na Sarajevo sa bombardovanjem rumunskog Ploeštija, najbombardovanijeg grada u jugoistočnoj Evropi na koji je bačeno 11613 tona bombi ili bombardovanjem Beča, gra-

\footnotetext{
${ }^{104}$ Efektivni borbeni let je let u kojem je izvršeno bombardovanje.
} 
da kojeg su najžešće bombardovale vazduhoplovne snage stacionirane u Italiji sa 27320 tona bombi, ${ }^{105}$ vidi se da je Sarajevo tokom većeg dijela Drugog svjetskog rata strategijski bilo marginalan cilj. Strategijski značaj Sarajeva raste ulaskom Crvene armije u Jugoslaviju, te onemogućavanjem povlačenja njemačkih snaga prugom Solun - Sofija - Beograd - Ljubljana i rijekom Dunav koji su bili strateške komunikacije u jugoistočnoj Evropi. U Bosni i Hercegovini je samo na Bosanski Brod u strateškim napadima bačena veća količina bombi, ukupno 1019 tona na rafineriju, željezničku stanicu i mostove između Bosanskog i Slavonskog Broda. ${ }^{106}$

Žrtve koje su izazvali napadi avijacije na Sarajevo i okolinu nisu precizno ustanovljene. Popisom žrtava Drugog svjetskog rata u Jugoslaviji koji je izvršen 1964. godine utvrđen je broj od 316 žrtava bombardovanja u Bosni i Hercegovini, ali njime nisu obuhvaćene žrtve koje su u ratu izgubile život od Narodnooslobodilačke vojske ili snaga antiosovinske koalicije. ${ }^{107}$ Iako su u ovom popisu žrtvama rata smatrani i civili stradali od vazdušnih bombardovanja, jasno je da je broj stradalih neproporcionalno mali. Smatra se da je u njemačkim napadima na Sarajevo 1941. godine poginulo oko 90 ljudi, dok je analizom različitih izvora broj poginulih u savezničkim napadima između 611 i 665. Broj žrtava savezničkih napada nije konačan, jer nakon dva najteža napada 8 . septembra i 7. novembra 1944. godine nije ustanovljen potpun broj žrtava, pošto je smatrano da je bilo stradalih čija su tijela potpuno raznesena. Međutim, mnogo je važnije naglasiti da su napadi na grad koje su izveli Nijemci i saveznici imali potpuno različite mete. Dok je cilj njemačkih napada bilo gradsko područje u kojem su i sami stanovnici bili meta, saveznička bombardovanja su bila usmjerena na ciljeve od vojnog značaja. Mogući razlog većeg broja žrtava savezničkih

\footnotetext{
${ }^{105}$ Vidi: G. R. Davis, Bombing the European Axis Powers, 541. Tonaža u izvoru je data u kratkim tonama, a ovdje u metričkim tonama.

${ }^{106}$ O tome: G. R. Davis, Bombing the European Axis Powers, CD-ROM, Table 1944-2.

107 Marica Karakaš Obradov, "Žrtve savezničkih bombardiranja Nezavisne Države Hrvatske u jugoslavenskim popisima žrtava rata (1947, 1950. i 1964.) i hrvatskim žrtvoslovima (1991. 2005.)", u: Polemos: časopis za interdisciplinarna istraživanja rata i mira 10, Zagreb: Hrvatsko sociološko društvo i Naklada Jesenski i Turk, 2007, 75.
} 
bombardovanja je što su saveznici bombardovanja vršili daleko većim snagama i u dužem vremenskom periodu nego Nijemci. Ukupno je u vazdušnim bombardovanjima gradskog područja Sarajeva tokom Drugog svjetskog rata stradalo između 700 i 750 osoba, što je oko 0,8\% populacije grada s početka Drugog svjetskog rata koja je iznosila oko 96.000 ljudi.

\section{IZVORI I LITERATURA}

Arhivski izvori

Historijski arhiv Sarajevo (HAS), Sarajevo

Kotarsko nadzorništvo narodne zaštite (KNNZ-12).

The National Archives of United Kingdom, Richmond

Air Ministry and successors: Operations Record Books.

Air Force Historical Research Agency (AFHRA):

Archived Air Force Publications and Forms.

\section{Objavljeni izvori}

Zbornik dokumenata i podataka o Narodnooslobodilačkom ratu jugoslovenskih naroda, tom IV, knjiga 20- borbe u Bosni i Hercegovini 1943. godine, Beograd: Vojni istorijski institut Jugoslovenske narodne armije, 1959.

Zbornik dokumenata i podataka o Narodnooslobodilačkom ratu jugoslovenskih naroda, tom V, knjiga 34- borbe u Hrvatskoj 1944. god-novembar, Beograd: Vojnoistorijski institut, 1966.

Zbornik dokumenata i podataka o Narodnooslobodilačkom ratu jugoslovenskih naroda, tom IV, knjiga 26- borbe u Bosni i Hercegovini 1944. god, Beograd: Vojnoistorijski institut, 1967. 
Zbornik dokumenata i podataka o Narodnooslobodilačkom ratu jugoslovenskih naroda, tom IV, knjiga 27- borbe u Bosni i Hercegovini 1944. god, Beograd: Vojnoistorijski institut, 1967.

Zbornik dokumenata i podataka o Narodnooslobodilačkom ratu jugoslovenskih naroda, tom V, knjiga 35- borbe u Hrvatskoj 1944. god. novembar, Beograd: Vojnoistorijski institut, 1967.

Zbornik dokumenata i podataka o Narodnooslobodilačkom ratu jugoslovenskih naroda, tom IV, knjiga 29- borbe u Bosni i Hercegovini 1944. godseptembar, Beograd: Vojnoistorijski institut, 1968.

Zbornik dokumenata i podataka o Narodnooslobodilačkom ratu jugoslovenskih naroda, tom IV, knjiga 30- borbe u Bosni i Hercegovini 1944, Beograd: Vojnoistorijski institut, 1968.

Zbornik dokumenata i podataka o Narodnooslobodilačkom ratu jugoslovenskih naroda, tom IV, knjiga 31- borbe u Bosni i Hercegovini 1944. godine, Beograd: Vojnoistorijski institut, 1968.

Zbornik dokumenata i podataka o Narodnooslobodilačkom ratu naroda Jugoslavije, dokumenti Njamačkog rajha 1944-1945, tom XII, knjiga 4, Beograd: Vojnoistorijski institut, 1979.

\section{Literatura}

\section{Knjige}

Barefield, Michael R, Overwhelming Force, Indecisive Victory: The German Invasion of Yugoslavia, 1941, Fort Leavenworth: School of Advanced Military Studies United States Army Command and General Staff College, 1993.

Davis, Richard G, Bombing the European Axis Powers-A Historical Digest of the Combined Bomber Offensive 1939-1945. Maxwell Airforce Base, Alabama: Air University Press, 2006.

Karakaš Obradov, Marica, Anglo-američka bombardiranja Hrvatske u Drugom svjetskom ratu: saveznički zračni napadi na Nezavisnu Državu Hrvatsku 1943.-1945, Zagreb: Hrvatski institut za povijest, 2008. 
Lazarević, Božo, Vazduhoplovstvo u NOR-u 1941-1945, Beograd: Vojnoizdavački zavod JNA, 1972.

Mahoney, Kevin A, Fifteenth Air Force against the Axis: Combat Missions over Europe during World War II, Lanham, Toronto, Plymouth UK: The Scarecrow Press, inc. 2013.

Mclean, Fitzroy, Eastern Approaches, Oxford: Alden Press, 1949.

Pettey, Jesse, One More Mission: A Journey from Childhood to War, Bloomington: Xlibris, 2001.

Richards, Dennis, Saunders, Hilary St. George, Royal Air Force 1939-1945, Volume II, The Fight Avails. London: HMSO, 1954.

Shores, Christofer et al. Air War for Yugoslavia, Greece and Crete, 1940-41, London: Grub Street, 1987.

\section{Članci}

Jefford, Jeff, “The Balkan Air Force”, u: Royal Air Force Historical Society Journal no. 46, Hendon: Royal Airforce Historical Society, 2009, 63-80.

Karakaš Obradov, Marica, “Žrtve savezničkih bombardiranja Nezavisne Države Hrvatske u jugoslavenskim popisima žrtava rata (1947, 1950. i 1964.) i hrvatskim žrtvoslovima (1991.-2005.)”, u: Polemos: časopis $z a$ interdisciplinarna istraživanja rata i mira 10, Zagreb: Hrvatsko sociološko društvo i Naklada Jesenski i Turk, 2007, 73-83.

Šefkić, Sulejman, "Stradanja stanovništva od prvih bombardovanja”, u: Sarajevo u revoluciji, knjiga 2- zbornik radova, Sarajevo: Istorijski arhiv Sarajevo, 1977, 88-95.

\section{Internetski izvori}

Drain, Richard E, $5^{\text {th }}$ Bomb Wing-History of Aircraft Assigned. Washington DC: Library of Congress, signatura: D790.D73, 2002. http:// www.2ndbombgroup.org/5thBombWingB-17sBook.pdf (pristupljeno: 28. 4. 2020) 
Fitzgerald, John C, $12^{\text {th }}$ Air Force, $57^{\text {th }}$ Bombardment Wing, $321^{\text {st }}$ Bombardment Group, History, http://57thbombwing.com/321stBombGroupHistory. php, 2013. (pristupljeno: 28. 4. 2020)

Milišić, Senija, "U izbjegličkom logoru Alipašin Most ubijeno je više od 200 osoba", STAV, Sarajevo, $2019<$ https://stav.ba/u-izbjeglickom-logoru-alipasin-most-ubijeno-je-vise-od-200-osoba/> 2019. (pristupljeno: 28. 4. 2020)

The Fifteenth Air Force. https://15thaf.org (pristupljeno: 28. 4. 2020)

The Fifteenth Air Force. https://15thaf.org (pristupljeno: 28. 4. 2020)

Zaimović, Haris, "Moderna historija Sarajeva pisana kroz 6. april (1): Sarajevo je do popodnevnih sati 6 . aprila 1945. bilo potpuno slobodno", u: STAV, Sarajevo, 2018 https://stav.ba/moderna-historija-sarajeva-pisana-kroz-6-april-1-sarajevo-je-do-popodnevnih-sati-6-aprila-1945-bilo-potpuno-slobodno/ 2018. (pristupljeno: 28. 4. 2020)

301th Bombardment Group. (H) https://301bg.com (pristupljeno: 19. 4. 2020)

449th Bomb Group WWII. https://449th.com (pristupljeno: 29. 4. 2020) The 446th Bomb Group. http://www.446bg.com (pristupljeno: 28. 4. 2020) 484th Bombardment Group (H). https://484th.org/ (pristupljeno: 28. 4. 2020)

461st Bombardment Group (H). https://461st.org/ (pristupljeno: 28. 4. 2020) 


\title{
AERIAL BOMBARDMENT OF SARAJEVO IN WORLD WAR TWO
}

\begin{abstract}
Summary
During World War Two Sarajevo was a target to the bomber aviation of both, German and Allied, air forces. Bombs hit every part of the town from Ilidza and Stup to Vratnik, Bistrik, and Bentbasa. German bombings in April 1941 were executed in order to Hitler's directive 25. They were relatively short and had two major goals, the annihilation of the Yugoslav Royal Air Force on airport Rajlovac and bombing of the residential parts of Sarajevo. These bombings were executed by the Luftwaffe's X Fliegerkorps (air corps). German bombings of the city took around 90 lives.

Allied bombings of the Balkan cities began in late 1943. From November 1943 to December 1944, Allied air forces attacked Sarajevo 15 times of which 10 effectively with 984,4 tons of bombs dropped. First attacks were executed by USAAF 12th Air Force and RAF Middle East Command and Balkan Air Force, while most devastating attacks were executed by USAAF 15th Air Force and RAF No.205 Bomber Group. During these bombings, bombs weighing up to $4000 \mathrm{lbs}, 1,8$ metric tons were dropped. The major objectives of Allied bombers were railroad installations which were hit by $99,5 \%$ of effective sorties with 979,4 tons of bombs. The most intensive bombings of Sarajevo were during November 1944 with 3/4 of total bombs dropped during the War. This corresponds with German Army group E withdrawal from Greece through Montenegro and Bosnia and Herzegovina which gave strategic importance to Sarajevo as a regional railroad junction. The number of victims of Allied bombings was not accurately determined and varies between 611 and 665 according to different sources. On two locations bombings caused massive killings when bombs hit a refugee camp in one attack, and penetrated a shelter full of people in another.
\end{abstract}

